\title{
IMPLIKASI TEORI BELAJAR SOSIAL (SOCIAL LEARNING THEORY) DARI ALBERT BANDURA DALAM BIMBINGAN DAN KONSELING
}

\author{
Tarsono \\ Fakultas Psikologi UIN Sunan Gunung Djati Bandung \\ Jl. Raya Cipadung No. 105 Bandung 10614 Telp (022) 7800525 email: tarsonomakmuri@yahoo.com
}

\begin{abstract}
One of many ways of conceiving individual personality is by observing and analyzing his or her behavior. Bandura said that we need to know how people interact with the world around them. Sometimes any actions and his or her interaction with environment can be contrary to values that holds by their society. However-Bandura was also point out and human behavior can be predicted and modified by altering their behavior through learning. This learning processes must also considering the capacity of each person according to each own ability to think and how they interact with their surrounding environment. Based on social learning theory, behavior can be altered and modified through modeling, which is used to shape and molding a new behavior that can be approved by society and eliminating any unwanted behavior. Basic principle from this modeling is a goal that client can create, shape and mold new behavior through imitation or copying someone else's behavior or people that become a model figure for them.
\end{abstract}

Keyword: social learning, modeling, counseling

\section{Pendahuluan}

Terdapat tiga aliran utama dalam teori kepribadian yaitu psikoanalisa, humanistik dan behavioristik. Teori behavioristik bersifat lebih obyektif, fungsional dan menekankan penelitian empiris, sedangkan kedua aliran yang lain lebih menekankan sisi subyektif dan intuitif terhadap perilaku manusia.

Salah satu tokoh dalam aliran behavioristik adalah Albert Bandura, yang dikenal dengan teori social learningnya. Dipilihnya teori ini karena pandangan Bandura bahwa perilaku manusia dapat diprediksi dan dimodifikasi melalui prinsip-prinsip belajar dengan memperhatikan kemampuan berpikir dan interaksi sosialnya. Manusia mampu mengatur diri sendiri dan mengontrol lingkungan di samping dibentuk oleh lingkungan. (Hall, 1981: 617)

Manusia adalah makhluk individual dan makhluk sosial. Sebagai makhluk sosial, manusia senantiasa berhubungan satu sama lain. Melalui interaksi tersebut ia mengalami proses belajar, karena pada dasarnya manusia melakukan kegiatan belajar sepanjang hidupnya. Keberhasilan proses belajar dipengaruhi oleh faktor dari dalam dan luar dirinya. Berdasarkan teori Bandura, faktor kognitif menjadi faktor internal dan lingkungan sebagai faktor eksternal dalam proses belajar untuk memodifikasi perilaku, dan perilaku manusia mewarnai interaksi sosial dalam lingkunganya. Dengan demikian, manusia bukan semata-mata sebagai obyek yang dipengaruhi lingkungan, akan tetapi juga mempengaruhi lingkungan. 


\section{Pembahasan}

\section{Riwayat Singkat Albert Bandura}

Albert Bandura lahir pada tanggal 4 Desember 1925 di Canada, dari keluar petani. Setelah SMU ia masuk ke University of British Columbia di Vancouver dan meraih B.A. pada tahun 1949. Ia melanjutkan pendidikan di University of Lowa jurusan Psikologi hingga meraih M.A. pada tahun 1951 dan Ph. D. Pada tahun 1952. Setelah selama satu tahun praktek klinis di Wichita Kansas Guidance, pada tahun 1953 ia diterima bekerja di Stanfort University. Selama karirnya, Bandura mengembangkan pendekatan social learning untuk memahami kepribadian manusia melalui peneletianpenelitian.

Beberapa buku yang ditulis Bandura yaitu: Adolescent Aggression (1959), Social Learning and Personality Development (1963), Principles of Behavior Modification (1969), Aggression: A Social Learning Analysis (1973), dan Social Learning Theory (1977). Penghargaan-penghargaan yang pernah di-terima yaitu: The Distinguished Scientist.

Award dari American Psychological Associaton pada tahun 1972, dan The Distinguished Scientific Achievement Award dari California Psychological Association pada tahun 1973.

\section{Prinsip-prinsip Teori Social Learning Bandura}

1. Hakikat Manusia

Penjelasan Bandura tentang teorinya seperti yang dikutip oleh Hall dan Lindzey (1981: 617), yaitu :
Social learning theory approaches the explanation of human behavior in terms of a continuous reciprocal interaction between cognitive, behavior and environmental determinants. Within the process of reciprocal determinism lies the opportunity for people to influence their destiny as well as the limits of selfdirection. this conception of human functioning then neither casts people into the role of powerless objects controlled by environmental forces nor free agents who can become whatever they choose. Both people and their environments are reciprocal determinants of each other.

Manusia dapat dipahami melalui interaksi timbal balik antara perilaku, kognitif, dan lingkungan. Hubungan ketiganya dapat digambarkan sebagai berikut :

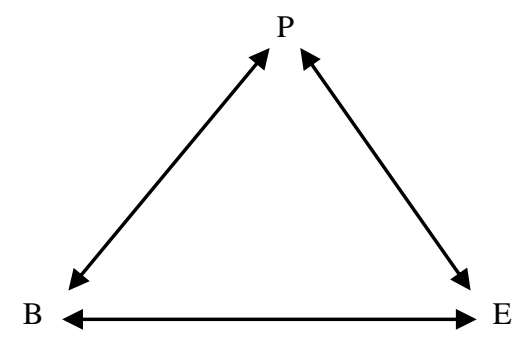

Gambar 1: Perilaku (B=Behavior), kognitif dan faktor personal $(\mathrm{P}=$ Personal $)$ serta lingkungan ( $E=$ Eenvironmental) saling menentukan satu sama lain. (diambil dari Hjelle \& Ziegler, 1981)

Pada dasarnya manusia mempunyai kemampuan untuk berpikir dan mengatur atau mengarahkan diri sehingga ia dapat pula mengontrol lingkungan, disamping manusia juga dibentuk oleh lingkungannya. dengan demikian, prilaku dipelajari individu melalui interaksi dengan lingkungan, dan perkembangan kepribadiannya tergantung pada interaksi tersebut. 


\section{Modifikasi Perilaku}

Dalam berinteraksi, individu melakukan pengamatan terhadap individu lain. Belajar dengan pengamatan dinamakan modeling. Dalam modeling terjadi proses peniruan terhadap model. Belajar dengan pengamatan (observasional learning) meliputi empat proses, sebagaimana gambaran berikut :

\begin{tabular}{|c|c|c|c|}
\hline $\begin{array}{c}\text { Attentional } \\
\text { proses }\end{array}$ & $\begin{array}{c}\text { Retentional } \\
\text { proses }\end{array}$ & $\begin{array}{c}\text { Motor } \\
\text { reproduction } \\
\text { proses }\end{array}$ & $\rightarrow \begin{array}{c}\text { Motivasional } \\
\text { proses }\end{array}$ \\
\hline $\begin{array}{l}\text { Person } \\
\text { attends to, } \\
\text { and } \\
\text { accurately } \\
\text { perceives } \\
\text { the } \\
\text { model's } \\
\text { behavior }\end{array}$ & $\begin{array}{l}\text { Person } \\
\text { remembers } \\
\text { (long-term } \\
\text { retention) } \\
\text { the model's } \\
\text { behavior } \\
\text { previously } \\
\text { obseved. }\end{array}$ & $\begin{array}{l}\text { Person } \\
\text { translate } \\
\text { symbolically } \\
\text { coded } \\
\text { memories of } \\
\text { the model's } \\
\text { behavior into } \\
\text { new response } \\
\text { patterns }\end{array}$ & $\begin{array}{l}\text { If positive } \\
\text { reinforcement } \\
\text { (external, } \\
\text { vicarious, or } \\
\text { self- } \\
\text { reinforcement) } \\
\text { is poteentially } \\
\text { present, person } \\
\text { performs } \\
\text { modeled } \\
\text { behavior. }\end{array}$ \\
\hline
\end{tabular}

Gambar 2: Proses-proses dalam observational learning (diambil dari Hjelle \& Ziegler, 1981)

Dalam observational learning, reinforcement merefleksikan orientasi kognitif. Reinforcement eksternal berfungsi sebagai informasi dan sebagai pendorong (incentive) bagi individu untuk menunjukkan suatu perilaku. Individu juga mempelajari reinforcement yang diperoleh model yang diamati dan ia dapat mereinforce dirinya sendiri.

Melalui kognitifnya, individu dapat melakukan self-control sehingga ia dapat mengarahkan dan mengatur dirinya. Dalam melakukan pengamatan terhadap orang lain, lingkungan dan perilakunya dapat dikelola sesuai dengan kemampuannya dalam berinteraksi.

Menurut Nelson-Jones (1995: 293) selain observational learning, proses belajar dapat dilakukan dengan cara enactive learning (belajar lewat peran) atau belajar dari pengalaman. Dalam enactive learning, individu mempelajari konsekwensi - konsekwensi yang menyertai suatu perilaku. Berdasarkan pe-ngalamannya terhadap konsekwensi tersebut, individu akan lebih mengembangkan keterampilannya hingga ia menemukan suatu bentuk perilaku yang lebih baik.

\section{Implikasi Teori Social Learning dalam Konseling}

1. Pemahaman Individu

Salah satu upaya untuk memahami individu adalah dengan memahami perilakunya. Berdasarkan teori Bandura untuk memahami perilaku individu maka perlu memahami interaksi individu tersebut dengan lingkungannya. Konselor perlu memahami bahwa lingkungan dapat membentuk perilaku individu dan lingkungan tersebut juga menggambarkan individu-individu yang ada di dalamnya. konselor perlu juga memahami bahwa munculnya motif-motif, dorongandorongan dan kebutuhan-kebutuhan klien merupakan pengaruh interaksi klien dengan lingkungannya (Hansen: 1982).

Dengan demikian untuk memahami klien dalam rangka proses konseling, konselor perlu mencari data pendukung dari lingkungan dimana klien berada. Lingkungan klien meliputi lingkungan keluarga, teman-teman atau lingkungan masyarakat lain. Yang perlu diperhatikan juga adalah kebiasaan-kebiasaan klien, misalnya acara TV atau film yang sering dilihatnya, buku-buku yang sering dibaca, 
lagu-lagu yang disukai, artis atau tokoh yang diidolakan. Hal-hal tersebut memungkinkan klien untuk meniru dan membentuk perilakunya.

Menurut Crain (1992:178) teori sosial learning menunjukkan bahwa perilaku tidak hanya dipengaruhi oleh personal atau model hidup, tetapi juga apa yang ditunjukkan oleh media massa. Media massa tersebut dapat berbentuk film, televisi, radio, buku, majalah, tabloid atau surat kabar.

\section{Tujuan Konseling}

Dalam konseling behavioral, Balcham dan Silberman (dalam Hansen at al, 1982) mengemukakan empat langkah khusus yang sebaiknya dilakukan dalam menentukan tujuan konseling dan metode yang digunakan untuk mengubah perilaku, yaitu :

a. Mendefinisikan permasalahan

b. Mengetahui sejarah sosial dan perkembangannya

c. Menetapkan tujuan konseling secara spesifik

d. Menentukan metode yang digunakan.

Ivey (1980) mengingatkan tentang keterbatasan konseling behavioral, yaitu jika konselor membuat keputusan tanpa adanya kesadaran klien atau klien tidak punya pilihan lain sehingga konselor sangat menguasai kehidupan klien, sebagaimana dikemukakannya bahwa :

Manipulative behavioral conseling accurs when the counselor makes a decision for the client without client awareness or when the counselor has so much power in the clinet's life that the client has no choice but to agree to the behavioral program whethet or not he or she agrees.

Dengan demikian, dalam menentukan tujuan konseling perlu melibatkan klien dengan sungguh-sungguh sehingga perubahan perilaku yang diharapkan akan menjadi tanggung jawab klien dalam pelaksanaannya. Perubahan perilaku yang menjadi tujuan koseling dapat berupa pengembangan atau pembentukan suatu perilaku maupun pengurangan atau penghilangan perilaku tertentu. Perubahan perilaku yang diharapkan dapat dilakukan melalui teknik-teknik konseling tertentu dengan melibatkan atau memperhatikan interaksi klien dengan lingkungannya.

\section{Proses Konseling}

Dalam proses konseling, faktor kehangatan, keterbukaan, penerimaan atau penghargaan dianggap perlu akan tetapi tidak cukup sebagai kondisi pengubah perilaku. Untuk itu dalam proses konseling perlu diciptakan kondisi yang memungkinkan klien dapat mempelajari perilaku baru melalui imitasi atau peniruan, terutama yang ditunjukkan oleh konselor atau anggota kelompok lain dalam konseling kelompok. Menurut Bandura dalam Corey (1991: 230) konselor menjadi model penting bagi klien. Klien seringkali meniru sikap-sikap, nilai-nilai dan perilaku konselor. Jadi konselor harus menyadari perannya dalam proses identifikasi yang dilakukan klien.

Dengan memahami implikasi teori Bandura dalam proses konseling ini, maka perlu disadari oleh para konselor pada 
umumnya, tidak hanya konselor dalam aliran behavioristik bahwa seorang konselor dituntut memiliki keterampilan dan kepribadian yang sesuai atau mantap. Konselor harus menyadari selama proses konseling dirinya menjadi model bagi klien baik dalam perilaku, nilainilai, norma-norma, bahkan keyakinan-keyakinannya yang diterima atau diamati klien, baik secara verbal maupun non verbal.

Yang perlu diperhatikan selama proses konseling, konselor hendaknya menciptakan hubungan agar klien merasa tidak dihakimi atau diadili tetapi klien merasakan bahwa konselor menyukainya dengan segala informasi mengenai masa lalunya, keluarganya, pengalaman-pengalaman, serta rencana-rencananya. Informasi ini sangat bermanfaat bagi konselor untuk memahami klien. Dalam memahami klien sangat dibutuhkan pemahaman mengenai bagaimana klien dapat menggunakan waktunya untuk melaksanakan proses konseling, sehingga kesepakatan yang dibuat dapat dilaksanakan dengan baik.

\section{Teknik-teknik Konseling}

Prosedur-prosedur yang digunakan dalam konseling berhubungan dengan prinsipprinsip belajar. Prosedur tersebut disusun untuk menambah dan memperkuat perilaku klien atau untuk mengurangi dan menghilangkan perilaku klien tertentu.

Prosedur yang disusun untuk membentuk perilaku baru atau mengembangkan beberapa perilaku diantaranya yaitu shaping, modeling atau assertive training. Sedangkan prosedur yang disusun untuk menghilangkan suatu perilaku yaitu desensitisasi atau extinction.

Hal terpenting dalam konseling behavioristik ialah program pengaturan atau manajemen diri (self management) untuk klien. Penggunaan prosedur konseling harus dibicarakan secara bersama-sama oleh konselor dan klien, karena klien mempunyai tanggung jawab untuk melaksanakan prosedur tersebut sedangkan konselor sangat berperan untuk mendukung klien.

Berdasarkan teori social learning, perilaku dapat dimodifikasi oleh interaksi klien dengan lingkungan. Salah satu teknik konseling yang disusun sesuai teori Bandura adalah teknik modeling.

Teknik modeling digunakan apabila koseling bertujuan untuk membentuk suatu perilaku baru bagi klien. Prinsip dasar dari teknik modeling ini adalah bahw klien akan memperoleh perilaku baru melalui imitasi atau peniruan terhadap seorang atau beberapa orang model. Akan tetapi menurut Hansen, modeling dapat pula untuk menghilangkan atau mengurangi perilaku tertentu dengan menggunakan tipe model tertentu.

Tentang tipe-tipe model, Hansen, Stevic dan Warner (1982) mengemukakan: "Four basic types o models have been used in counseling; filmed, taped, live and self-as-amodel". Untuk model dengan tape atau film, klien melakukan peniruan perilaku dari film atau tape sesuai petunjuk yang telah dibicarakan dengan konselor. Model tipe ini efektif untuk menyelesaikan masalah-masalah yang berkaitan dengan kognitif. Dalam model 
live (hidup), klien mempelajari atau meniru perilaku dari teman-teman anggota kelompoknya dalam konseling kelompok yang dilakukan dan konselor memberikan reinforcement positif untuk memperkuat perilaku yang ditunjukan klien. Model tipe ini sangat efektif untuk menangani masalah-masalah pribadi dan sosial. Sedangkan dalam self-as-a-model, klien diminta untuk mengamati dirinya sehingga diketahui perilaku-perilaku yang dimiliki, kemudian klien menentukan perilaku mana yang ingin dihilangkan atau diubahnya. Model ini lebih sesuai untuk masalah-masalah seperti penerimaan diri (self-acceptance) atau keterampilan intepersonal.

Menurut Bandura, seperti yang dikemukakan Crain (1992: 178) bahwa klien akan mempelajari perilaku baru atau tidak, tergantung pada empat faktor yaitu: attention atau perhatian klien terhadap perilaku model, retention atau upaya klien untuk mengingat perilaku yang akan ditirunya, motor production atau keterampilan klien untuk mewujudkan perilaku yang diharapkan dan incentive atau reinforcement yang akan mendorong atau memperkuat perilaku yang ditunjukkan klien.

Dalam teknik modelling nampak bahwa perilaku klien terbentuk karena adanya interaksi sosial klien dengan model yang berada dalam lingkungannya, dan perilakuperilaku yang ingin dibentuk dipahami oleh klien terlebih dahulu, sehingga memulai kemampuan atau kognisinya, klien dapat melakukan pengaturan dirinya untuk mewujudkan perilaku yang diinginkan.
Secara umum implikasi teori social learning dalam bimbingan dan konseling digambarkan dalam tabel berikut:

\begin{tabular}{|c|c|c|c|c|}
\hline \multirow[b]{2}{*}{$\begin{array}{l}\text { Konsep } \\
\text { Kunci }\end{array}$} & \multicolumn{4}{|c|}{ Komponen-komponen Bimbingan dan Konseling } \\
\hline & $\begin{array}{c}\text { Pemahaman } \\
\text { Individu/Klien }\end{array}$ & $\begin{array}{c}\text { Tujuan } \\
\text { Konseling }\end{array}$ & $\begin{array}{c}\text { Proses } \\
\text { Konseling }\end{array}$ & $\begin{array}{c}\text { Teknik } \\
\text { Konseling }\end{array}$ \\
\hline $\begin{array}{l}\text { Hubungan } \\
\text { timbal balik } \\
\text { antara perilaku, } \\
\text { kognitif dan } \\
\text { faktor } \\
\text { lingkungan. }\end{array}$ & $\begin{array}{l}\text { Untuk } \\
\text { memahami } \\
\text { perilaku klien, } \\
\text { konselor perlu } \\
\text { mencari data } \\
\text { tentang } \\
\text { lingkungan } \\
\text { klien. } \\
\end{array}$ & $\begin{array}{l}\text { Perubahan } \\
\text { perilaku } \\
\text { dengan } \\
\text { melibatkan } \\
\text { interaksi klien } \\
\text { dengan } \\
\text { lingkungannya }\end{array}$ & $\begin{array}{l}\text { Diagnosis } \\
\text { juga meliputi } \\
\text { keadaan } \\
\text { lingkungan } \\
\text { klien }\end{array}$ & - \\
\hline $\begin{array}{l}\text { Belajar melalui } \\
\text { pengamatan } \\
\text { (observational } \\
\text { learning) }\end{array}$ & $\begin{array}{l}\text { Konselor } \\
\text { perlu } \\
\text { mengetahui } \\
\text { hal-hal yang } \\
\text { sering diamati } \\
\text { klien. }\end{array}$ & $\begin{array}{l}\text { Perubahan } \\
\text { perilaku } \\
\text { dengan melalui } \\
\text { contoh yang } \\
\text { dapat diamati } \\
\text { oleh klien }\end{array}$ & $\begin{array}{l}\text { Selama } \\
\text { proses } \\
\text { konseling, } \\
\text { konselor } \\
\text { menjadi } \\
\text { model bagi } \\
\text { klien } \\
\end{array}$ & $\begin{array}{l}\text { Teknik } \\
\text { modeling. }\end{array}$ \\
\hline $\begin{array}{l}\text { Proses kognitif } \\
\text { dalam diri } \\
\text { individu } \\
\text { menghasilkan } \\
\text { self- } \\
\text { management }\end{array}$ & - & $\begin{array}{l}\text { Melibatkan } \\
\text { kesadaran dan } \\
\text { kesepakatan } \\
\text { dari klien }\end{array}$ & $\begin{array}{l}\text { Diagnosis } \\
\text { dan } \\
\text { prognosis } \\
\text { diarahkan } \\
\text { pada } \\
\text { kemampuan } \\
\text { klien untuk } \\
\text { merubah } \\
\text { perilaku }\end{array}$ & - \\
\hline $\begin{array}{l}\text { Reinforcement } \\
\text { diperoleh dari } \\
\text { luar maupn } \\
\text { dari dalam diri }\end{array}$ & - & $\begin{array}{l}\text { Pengembangan/ } \\
\text { pembentukan } \\
\text { atau } \\
\text { pengurangan/ } \\
\text { penghilangan } \\
\text { perilaku } \\
\text { dengan } \\
\text { menggunakan } \\
\text { penguatan }\end{array}$ & - & $\begin{array}{l}\text { Teknik } \\
\text { reinforcement }\end{array}$ \\
\hline
\end{tabular}




\section{Daftar Pustaka}

Corey, Gerald (1991). Theory and Practice of Counseling and Psychotherapy. California: Cole Publishing Company.

Crain, William, (1992). Theories of Development: Concept and Applications. Third Edition. Englewood Cliffs: Prenice Hall, Inc.

Hall, Calvin S. \& Lindzey, Gardner (1981). Theories of Personality. New York: John Wiley \& Sons, Inc.

Hansen, James C., Stevic, Richard R., Warner, Richard W. Jr. (1982). Counseling Theory and Process. Massachusetts, Boston: Allyn and Bacon, Inc.

Ivey, Allen E. (1980). Counseling and Psychotherapy: Skills, Theories adan Practice. Englewood Cliffs: Prentice Hall, Inc.

Hjelle, Larry A., Ziegler, Daniel. (1981). Personality Theories: Basic Assumpations Research and Applications. Second Edition. Auckhland: Mc. Graw-Hill.

Nelson, Richard \& Jones (1995). Counseling and Pesonality: Theory and Practice. Sydney: Allen \& Unwin Pty Ltd. 
Psympathic, 2010, Vol. III, No.1: 29-36 